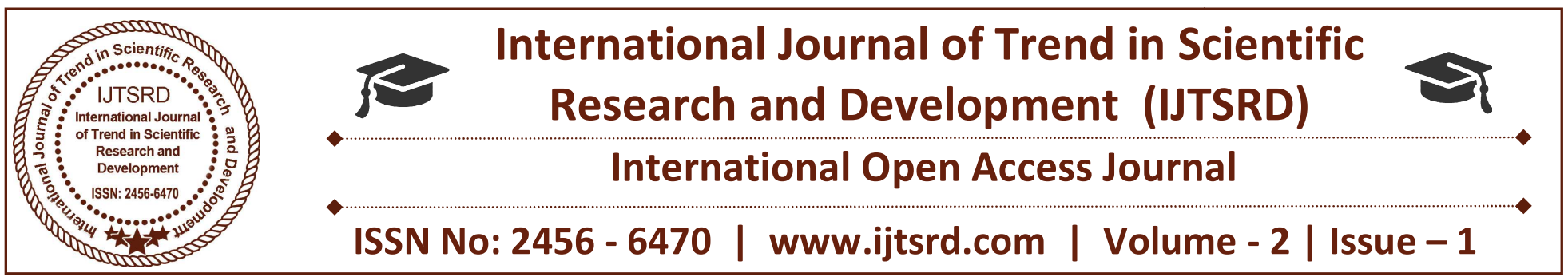

\title{
Shakespeare's The Tempest as a Tragicomedy
}

\author{
Ishfaq Hussain Bhat \\ Department of English,University of Kashmir, \\ Thune, Kangan, Ganderbal, Jammu and Kashmir
}

\section{ABSTRACT}

William Shakespeare (1564-1616) is beyond doubt the greatest dramatist of all time. He occupies a position unique in world literature. Other poets, such as Homer and Dante, and novelists, such as, Leo Tolstoy and Charles Dickens, have transcended national barriers; but no writer's living reputation can compare to that of Shakespeare. ${ }^{1}$ His plays, sonnets and two long narrative poems earned him an international acclaim and acceptance as the best writer in the history of English literature. His play, The Tempest, is thought by many critics to be the last play that Shakespeare wrote alone. In this play Shakespeare artistically blends aspects of both tragic and comic forms ${ }^{2}$ : a sorrowful scene is immediately followed by an amusing scene and vice versa. On one hand, the play has enough comic elements to lighten the tragic elements and on the other hand it has enough tragic elements to intensify the comic elements. The paper aims to study The Tempest as a tragicomedy by highlighting Shakespeare's artistic technique of blending tragic and comic elements in the play.

Keywords: tragicomedy, comic, tragic, happiness, sorrow

A tragicomedy is a work which does not fit with either a tragedy or a comedy: It is not light hearted enough to be called a comedy and it does not include death or any other awful event to be called a tragedy. A tragedy is basically a serious story which often involves the death of one or more characters and it generally has a tragic end. A comedy is a lightened, funny story that has a happy ending. A tragicomedy, thus, is a play that is neither a comedy nor a tragedy, although it has the features of both. ${ }^{3}$
It is difficult to categorize The Tempest as either a tragedy or a comedy. The published versions of Shakespeare's work also make it difficult to determine what he Intended. The First Folio classified The Tempest as a comedy. Later published collections classify it as a 'Romance' but this is not a really accurate category to use, either. The Tempest contains no major love story in its plot, so the term 'Romance' does not seem to be suitable. The play does have certain comic elements: the characters of Caliban and Ariel are often played for comic relief. However, it is also possible for both of these characters to be played with more tragic context: both are bound by servitude, and beg for their freedom, which makes them somewhat tragic. Caliban is ostracized for being ugly; this can also be comic or tragic, depending on the portrayal in the performance. Prospero's age and occasional befuddlement can also be played for either comic or tragic effect. Because the play contains elements of both the genres, it has been referred to by some critics as a "tragicomedy". This seems to be the best working term to refer to this play that defines placement in either genre. ${ }^{4}$

While going through The Tempest we are struck by a fact which supports the view that this play is a tragiccomedy. We find that, in this play, tragic events are immediately followed by amusing situations, and that amusing situations then immediately give way to serious and sad happenings. In certain scenes, we find the serious and sad events blending with the amusing elements. In the very opening scene we witness a ship being tossed by the sea-waves, it is threatened with destruction and the Passengers find themselves faced with an impending catastrophe : (Paul, 193) 
"Mercy on us.

We split, we split, farewell my wife, my children, Farewell brother: we split, we split, we split.”( Tempest, 5)

But in the midst of the danger and the anxiety, we find Gonzalo making remarks which greatly amuse us. (Paul, 193):

Gonzalo: "I have a great comfort from this fellow: methinks he hath no drowning mark upon him, his complexion is perfect gallows: stand fast good Fate to his hanging, make the rope of his destiny our cable, for our doth little advantage: if he be not born to be hang'd, our case is miserable." (Tempest, 4)

Antonio also makes witty remarks which greatly amuse us:

"Hang, cur, hang, you whoreson, insolent noise-maker, we are less afraid to be drown'd, than thou art." ( The Tempest, 4)

The scene which follows is full of sadness because here Prospero gives his daughter a detailed account of the misfortunes which he and she had experienced as a consequence of the perfidy of his brother Antonio who had been abetted by King Alonso and Sebastian (Paul, 193). This scene is replete with seriousness, dismay and sorrow:

\section{Prospero:}

"Twelve year since, Miranda, twelve year since,

Thy father was the Duke of Milan and

A Prince of power.

...By foul play were we heav'd thence,

But blessedly holp hither...

My brother and thy uncle, call'd Anthonio:

...in my false brother

Awak'd an evil nature, and my trust

Like a good parent, did beget of him

A falsehood in its contrary..."

(Tempest, 7-10)
When Ariel asks Prospero to free him, Prospero reminds him the sufferings to which Ariel had been subjected to by the witch, Sycorax. The tragic elements of the play get manifested through his speech full of pathos, sorrow and seriousness:

"Dost thou forget

From what a torment I did free thee?

...hast thou forgot

The foul Witch Sycorax, who with age and envy

Was grown into a hoop?...thou my slave,

As thou report'st thyself, was then her servant,

...And in her most unmitigable rage

Into a cloven pine, within which rift

Imprison'd, thou didst painfully remain

A dozen years: within which space she died,

And left thee there...thou best know'st

What torment I did find thee in; thy groans

Did make wolves howl...it was mine Art...

That made gape the pine, and let thee out."

(Tempest, 14-16)

This scene replete with pathos is immediately followed by a scene in which Ferdinand falls in love with Miranda who fully reciprocates his love. Throughout the following scene there runs a vein of comedy. Antonio and Sabastian continue to make sarcastic remarks about Gonzalo and Gonzalo hits back. The scene which follows is wholly comic. Trinculo and Stephano come upon Caliban who seems to them to be a monster and who, after getting drunk, himself becomes a comic character. (Paul, 193-94). Caliban is Prospero's servant. When Prospero was shipwrecked on the island Prospero treated him kindly but their relationship changed when

Caliban tried to rape Prospero's daughter, Miranda. He then became Prospero's unwilling servant. Commenting on the relationship between Prospero and Caliban, Meredith Anne Skura states: 'Caliban's 
childish innocence seems to have been what first attracted Prospero, and now it is Caliban's childish lawlessness that enrages him." (Skura, 65).The third Act of the play also presents a juxtaposition of the comic and the tragic elements. Caliban, Stephano and Trinculo appear once again and their entire conversation is greatly amusing, with Ariel invisibly playing tricks to create a misunderstanding among them. The only serious note in this scene is the conspiracy which the three men hatch against Prospero at Caliban's suggestion.( Paul, 194):

Caliban:

"As I told thee, 'tis a custom with him

I' th' afternoon to sleep: there thou mayst brain him,

Having first seiz'd his books: or with a log

Batter his skull, or paunch him with a stake,

Or cut his wezand with thy knife."

(Tempest, 48)

Stephano:

"Monster, I will kill this man: his daughter

And I will be King and Queen, save our Graces: and

Trinculo and thyself shall be Viceroys: dost thou like

The plot, Trinculo?"

(Tempest, 49)

This is followed by a romantic sub-plot in which Ferdinand and Miranda's love develops and Prospero, feeling fully satisfied with Ferdinand's conduct, agrees to the marriage of the lovers. Prospero also arranges a masque for the entertainment of the lovers.(Paul, 194):

Prospero to Ariel:

"...go bring the rabble here, to this place:

Incite them to quick motion, for I must

Bestow upon the eyes of this young couple Some vanity of mine Art: it is my promise, And they expect it from me."

(Tempest, 56)
Act $\mathrm{V}$ of the play is largely serious; it has a large component of serious and painful developments, though the whole thing ends happily. In the beginning of this Act, Ariel reports to Prospero the miserable condition of the three sinners who had been imprisoned by him in a lime-grove. It also presents the sad plight of Gonzalo who is shedding tears. Ariel pleads for the mercy towards the sufferers. (Paul, 195):

“...all prisoners Sir,

In the line-grove which weather-fends your cell,

They cannot budge till your release: the King,

His brother, and yours, abide all three distracted,

And the remainder mourning over them,

Brimful of sorrow, and dismay: but chiefly

Him that you term'd sir, the good old Lord Gonzalo,

His tears run down his beard like winter's drops."

(Tempest, 65)

The scene in which Prospero, reminds Alonso of the heinous crime which he had committed twelve years ago is equally pathetic. He also reminds Sebastian and Antonio of their obnoxious and hateful misdeeds:

"Home both in words, and deed; most cruelly

Did thou Alonso, use me, and my daughter:

Thy art pinch'd for 't now Sebastian. Flesh and blood,

You, brother mine, that entertain'd ambition,

Expell'd remorse, and nature, who, with Sebastian

Would here have kill'd your king: I do forgive thee."

(Tempest, 67)

Conforming to the genre of tragicomedy, this scene of sadness and grief is followed by a scene which proves to be a source of great joy and happiness to all concerned. Alonso is reunited with his son Ferdinand who is engaged to marry Prospero's daughter 
Miranda. Ariel is granted freedom for which he has been longing (Paul, 196):

“...my Ariel; chick

That is thy charge: then to the elements

Be free, and fare thou well: please you draw near."

(Tempest, 76)

Thus the happy ending of the play obliterates the tragic elements or at least diminishes their effect considerably. (Paul, 196)

According to the Greek philosopher Aristotle, a play is a tragedy if everyone suffered in the end, even the innocent; a play is a comedy if the innocent triumph and only the wicked come to the horrible end. During Renaissance, tragicomedy became an accepted genre in which the ending was happy, but it contained themes like danger, fall from position, it also contained comic elements. Looking at tragicomedy through this lens, we can see that it applies to Shakespeare's

The Tempest perfectly. On one hand serious issues normally portrayed in tragedies are present, including Prospero's fall from power, the murder plot of Sebastian and Antonio against Alonso, and the theme of revenge, On the other hand, we have a romance between Ferdinand and Miranda, a humorous sub-plot with the low-class Stephano and Triniculo, and the lighter elements of the bridal masque and harmless magic. Ultimately when Prospero draws those who have wronged him into his magic circle, the play hangs in the balance between comedy and tragedy: Will he take revenge on those who have wronged him showing himself to be no better than they? Or will he overcome his desires for retribution and heed his higher nature? He eventually forgives those who have wronged him. The technique of blending tragic elements with comic elements employed by Shakespeare makes The Tempest a perfect example of tragicomedy. ${ }^{6}$

\section{Works Cited:}

1) Shakespeare, William. The Tempest. Peocock Books. 2006. Print.

2) Paul, Rajinder. The Tempset. Rama Brothers India Pvt. Ltd. 2007. Print.

3) Skura, Meredith Anne. "Discourse and the Individul": The Case of Colonialism in The Tempest.

4) Shakespeare Quarterly 40 (1989)

\section{Web Sources:}

1) https://www.britannia.com/biography/williamshakespeare-literary-criticism

2) https://en.m.wikipedia.org/wiki/tragicomedy

3) https://www.enotes.com/homework-help/whydoes-tempest-by-shakespeare-considered-153181

4) https://www.enotes.com/homework-help/howtempest-tragic-comedy-586139

5) https://www.bartleby.com/essay/Relationshipbetween-Prospero-Caliban-and-Ariel-inF3JMBRYTJ

6) https://www.enotes.com/homework-help/whydoes-tempest-by-shakespeare-considered-153181 